\title{
Developing a Corporate Image Model
}

\section{H van Heerden}

Department of Marketing and Communication Management, University of Pretoria

\section{ABSTRACT}

A survey of current literature and corporate identity manuals may create the impression that corporate identity consists solely of visual identity cues. In this paper the view is explored that corporate identity consists of both visual and behavioural cues. Most corporations strive towards a positive corporate image. This can be attained only by taking into account also such aspects as customer service and employee behaviour, and not just creating attractive buildings, uniforms, logos and slogans. An analysis of selected literature and the results of four independent studies are reported to support the proposal of a Corporate Image Model that needs further research and refinement.

JEL Ml4

\section{INTRODUCTION}

Marketing and communication managers might be under the impression that corporate identity consists solely of visual and graphical artefacts. In a previous paper (1994) this author stated that a review of South African corporate identity manuals may create the impression that a well-designed corporate livery package, consisting of a well-known name, a distinctive logo, visually appealing premises, and attractive colours, are the most important factors contributing to a desired corporate image.

However, the main argument pursued here is that corporate identity cues (both visual and behavioural) create impressions or perceptions in the minds of corporate audiences to form an overall corporate image. It is thus assumed that a visual identity cue, such as a corporate logo, may serve as a cognitive "switch" to recall an image in the mind of the beholder, essentially based on behavioural cues experienced in the past. This means that though an image of the corporation may be recalled by an element of visual design, it in effect consists of the perceived behaviour of the corporation. 
The view that corporate identity consists of both visual elements and the way that the corporation behaves (Bernstein, 1986; Band, 1987; Bellhouse, 1989; and Croft, 1989), is the subject explored in this article.

\section{LITERATURE REVIEW}

Some theoretical constructs must be revisited before developing a model to explain the corporate image process.

The establishment of a corporate image, personality, and reputation is similar to the establishment of an individual person's image, personality, and reputation. Bad behaviour leads to a negative image, whether the individual is well-dressed or not. Suitable clothing may create a favourable first impression but thereafter behavioural traits will either maintain or change that impression. This argument also applies to corporations. An attractive and suitable name, logo and slogan (identity) might create a good first impression, but inconsistency or decline in service or dishonest treatment, will give a corporation an unfavourable or bad image.

\subsection{Corporate personality determines corporate identity}

The corporate image process starts with the corporate personality. Abratt (1989) says that the corporate personality is the sum total of the corporation's behavioural and intellectual characteristics. This personality is projected by conscious cues (corporate identity), such as customer service, products, and the company logo. These cues create impressions or perceptions in the minds of the audiences to constitute an overall corporate image.

Bernstein (1986: 40) defines personality "as the soul, the persona, the spirit, the culture of the organisation". It can be inferred that a corporation may like to manipulate its identity by managing a visual corporate identity programme and setting behavioural benchmarks (such as customer service levels) but it cannot readily manipulate its image, because the image is formed in the minds of target audiences.

Where does corporate identity then start? How does it evolve? What does it consist of? Olins (1989) makes the point that purpose and belonging are the two major facets of identity. Because every corporation is unique, it is essential that the corporate identity should spring from its roots, personality, strengths, and weaknesses. Sternberg (1991) reasons that corporate identity is all about values - corporate values, societal values, and living values. These values direct operations and the behaviour of management and employees. These values are 
manifested through visual identity cues and emphasised or reinforced by behavioural cues. This view is supported by Bellhouse (1989) who states that a corporate identity comprises two main elements - corporate behaviour and visual appearance.

Managing the corporate identity programme therefore aims to create coherence, symbolism, and positioning, a view supported by Olins (1989).

First, the corporation wants its different parts (business units, operations and product/service output) to relate to each other so that people can find their way around its divisions, corporations, and brands - coherence;

Second, the corporation wants to symbolise its vision and mission so that everyone who works for it can share the same spirit and then positively communicate it to all other people who deal with the corporation - symbolism; and

Third, the corporation wants to differentiate itself and its goods or services from those of its competitors in the market place - positioning.

\subsection{Corporate identity creates corporate image}

Bernstein (1986:39 \& 40) explains that "Corporate image is the net result of the interaction of all the experiences, beliefs, feelings, knowledge and impressions that people have about a corporation" and "identity means the sum of all the ways a corporation chooses to identify itself to all its publics".

The overall impression formed in the minds of audiences by certain identification cues, like logo, products, and customer service therefore constitutes a company's image. Selame and Selame (1988) condensed this to the effect that identity is what a corporation really is, while image means how the corporation appears to its audiences.

\subsection{Corporate logo}

The corporate logo can be described as a word, name, symbol, picture, device, or any combination of these, used by an institution to identify itself and to distinguish it from its competitors (Selame \& Selame, 1988). A single logo is often sufficient to be repeated on all corporate livery. The logo is a recognition symbol and may be seen as a stamp of approval and promise that the corporation behind this seal can be trusted. 
It may therefore be said in summary that corporate personality - management style, organisation policy, personnel and organisational goals, plus the corporate identity - behavioural attributes, such as level of customer service and visual attributes, like the corporate logo, buildings and uniforms create the corporate image in the minds of corporate stakeholders.

\subsection{Marketing effects enabled by a positive corporate image}

A well-managed corporate identity is one of a company's most valuable marketing assets. It determines the corporate or business strategy, structure and personality, and in this way attempts to transmit it across to the public as clearly as possible. Both large and small organisations wish to present themselves to their customers and employees in a harmonious and consistent manner. This can, inter alia, be done by making use of a series of graphic symbols, a certain layout, colour and letter-type on a company's products, as well as its letterheads.

However, the corporate identity usually entails much more than a single logo, brand name or trademark. The logo does not only appear on an piece of paper. It is a statement on aspects like who and what the company is, what it stands for and the product or service quality that can be expected from the company. It is here that the essential difference in style, personality and uniqueness of one corporation differentiates it from another. A clear corporate identity is important because people prefer to deal with companies that are well known (Harris, 1995).

The corporate identity addresses different stakeholders or audiences. When an organisation's image is improved, this has without doubt a great influence on the employee as well as the customer. It changes the way people look at a corporation and also their opinion of it. An image of quality improves employee morale and motivation and makes them proud of their workplace - and then would probably offer better service to internal and external customers. Many people would like to work for a progressive organisation, and it is therefore easier to employ better quality people. The corporate image should be frequently evaluated. This promotes a better understanding of stakeholder opinions and needs and how to address them. It creates goodwill, support and loyalty on the part of all stakeholders - the first step to relationship marketing.

There is a link between image management and marketing planning. Organisational marketing consists of activities to create, maintain, or change the attitudes and behaviour of target audiences towards an organisation. This calls for assessing the organisation's current image and developing a marketing plan to improve it (Kotler \& Armstrong, 1993). 
Corporate identity is of strategic marketing importance, because it is one of the key elements necessary to construct an image in people's minds (Stewart, 1991). Therefore, the projection of a favourable corporate image by means of a controlled, pre-planned corporate identity is a very important instrument in corporate and marketing strategy. This is how an organisation can focus its market segmentation, product and service positioning and integrated marketing communication approach.

\subsection{What is the marketing value of corporate image and identity?}

A number of authors like Katz (1988), Lener (1989), Ind (1990), Miller (1990), Cullen (1991), Skinner and Von Essen (1991) have expressed opinions on corporate identity and image, but their real marketing value has not been clearly stated. According to Gregory (1991), the marketing value of corporate image and identity as the cutting edge of corporate strategy, can be summarised as having the following aims:

- building public awareness of what the corporation stands for and establishing a more favourable market position in relation to suppliers, intermediaries, customers and competitors;

- redefining the corporation after a merger, take-over, acquisition, or name change;

- pre-selling communication to target markets to support product and service marketing;

- influencing shareholders and the financial community to increase their perception of the investment equity of the corporation;

- establishing the corporation's position on emerging issues in the market place;

- assisting management in a crisis to protect the corporate reputation;

- attracting and holding quality employees, and motivating them to promote a co-operative environment in their communities;

- indicating a shift in long-term corporate strategy;

- establishing the corporation in specific markets;

- reflecting a major change in product lines or operations;

- becoming more market-driven to aid differentiation, positioning and relationship building.

\subsection{Marketing and communication advantages of a good corporate image}

A solid image plan is a necessary tool to retain existing clients and generate new business (Abramic, 1993). Maintaining or expanding market share, keeping customer and business relations loyal, pre-empting competitive moves, and 
maintaining a profitable position, will depend on differentiation and a unique positioning in the minds of the corporate audiences.

Sunter (1993) states that the only way consumers will be able to differentiate between institutions in the future is through image and brand. The importance of having a well-defined identity is therefore necessary to all corporations, as competition increases by the crowding of businesses in certain areas. A wellconceived corporate image can lead to high awareness, loyalty, and a reputation of being well-liked.

Another important factor in the image-making process is customer service. The characteristics of services are defined by Stanton et al. (1991) and Kotler (1988), as being intangible, inseparable, heterogeneous, perishable, and having fluctuating demand. Service providers should note that their services would be all but anonymous without a brand name or the endorsement represented by a strong corporate identity (Thomas, 1988).

Because service quality is difficult to judge, corporations should take great care to keep quality as consistent as possible, and to maintain high levels of quality control so that customer expectations can be met. Stanton et al. (1991) state that "Quality is defined by the consumer and not by the producer-seller of a service".

Based on present marketing and communication principles, trends visible in the market and current literature on the subject, the following advantages are summarised below:

- corporate image may be a decisive factor in the consumer choice of goods and services;

- building a favourable corporate image becomes especially relevant in communities where the company is a major force. Of particular importance here is the company's position on social responsibility;

- a strong corporate image can improve the financial structure of a company and raise the appeal of its securities amongst potential investors and shareholders;

- building a favourable corporate image can be advantageous when public perceptions of a company do not reflect reality, are not clearly formed, or when vestiges of past management mistakes, plant accidents, poor earnings, environmental problems and the like may still be having a negative impact; and

- corporate image building is also very important when extemal forces like increased or new competition, breakthrough products and technologies, deregulation, or an existing competitor's new identity focus call for countermeasures. 


\subsection{A Corporate Image Process Model}

The following model is designed to summarise the literature on this subject. The research that follows here, attempts to test its theoretical soundness and the role of visual and behavioural factors in determining the corporate image. An element of measurement is added, because the following gaps need to be measured and rectified:

- company promises versus actual performance;

- corporate identity aims versus the real image attained; and

- corporate personality versus the real image attained.

Figure 1

Modelling the corporate image process

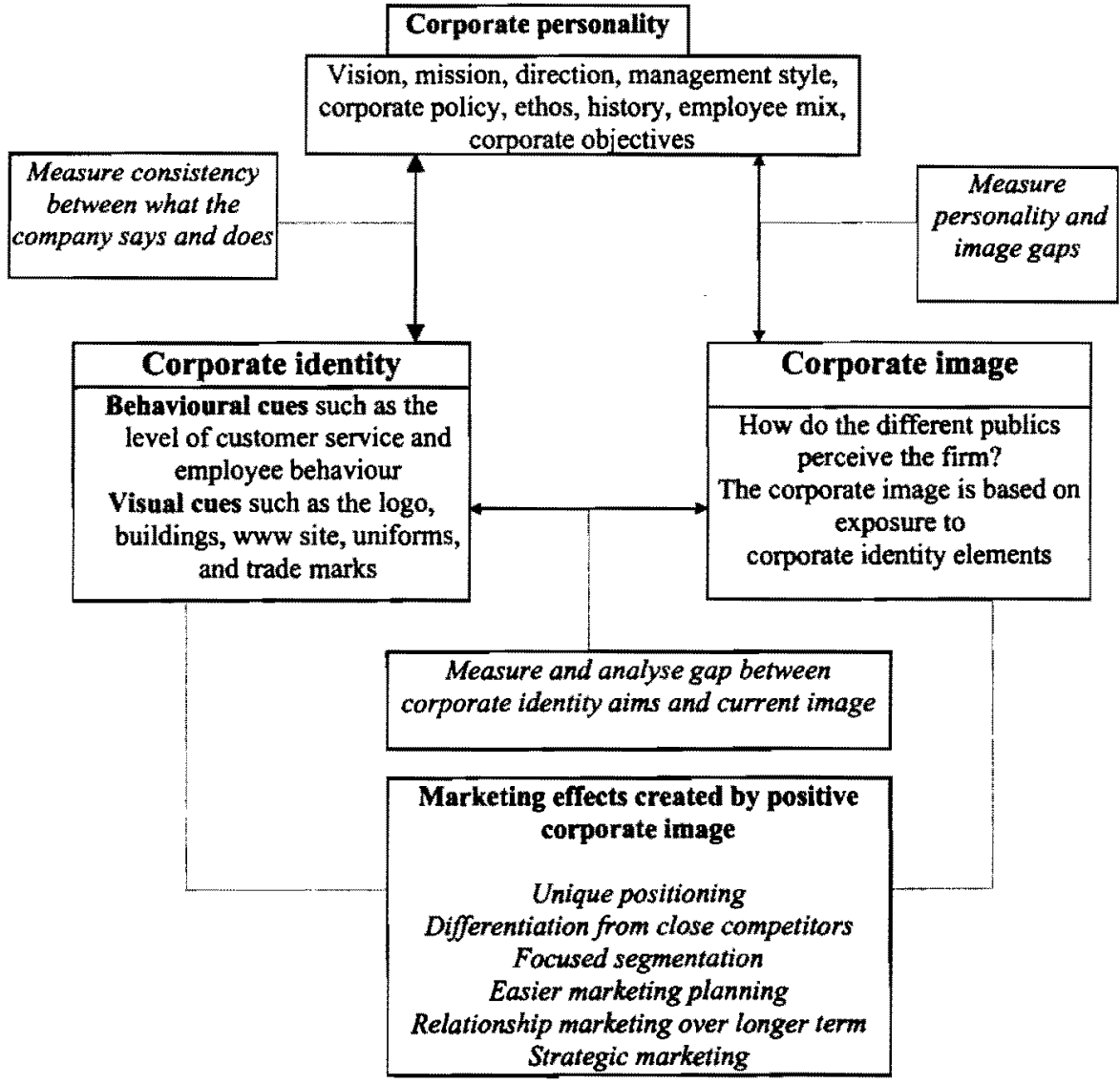




\section{RESEARCH METHODOLOGY}

\subsection{Introduction}

Since 1993 various South African industries (banking institutions, fashion retailers, petrol companies and fast food outlets) have been the objects of research in an ongoing research project by the Department of Marketing and Communication Management at the University of Pretoria.

The research methodology has developed since 1993, from a more general study of the factors that determine the corporate image of South African banking institutions (Van Heerden, 1993) and fashion retailers (Van den Berg, 1995) to more extensive multi-faceted projects on petrol companies (Beisiegel, 1996) and fast food outlets (Gouverneur, 1997).

Students were used as respondents, because they are important customers of all these industries and, according to Pitt and Nel (1989), good representatives of all consumers when the research involves human-information testing.

Each research project had the following main objectives:

- to develop a Semantic Differential (SD) consisting of a set of bi-polar items created for each industry;

- to expose respondents the corporate logo of different companies while completing the SD.

The reasons why the various South African companies (as research objects) and university students (as respondent groups) were chosen for this study, may be summarised as follows:

Banking institutions, fashion retailers, petrol stations and fast food outlets are/have:

- widely used;

- commercially visible through their many branches or outlets near the campus;

- very competitive;

- highly visible in advertising and sponsorship;

- distinctive logos;

- targeting the respondents used in this investigation, namely students, as important markets. 


\subsection{Research design}

The foundation of the study was to apply a semantic differential and different corporate logos as associative instruments to measure the perceptions of the respondent groups.

The research process therefore consisted of:

- generating and refining a set of bi-polar items that defines a semantic differential scale;

- recalling perceptions through a specific concept or construct - the corporate logo;

- asking a number of respondents to rate their perceptions of South African companies on the semantic scale;

- refining these responses through factor analysis in order to identify a smaller number of factors that determine the corporate image of the companies.

\subsection{Research procedure}

Data collection:

The data collection process was done at class meetings. A repeated measure design was used to gather the information needed for the studies.

Items included in the semantic differential:

In all four studies, a different set of bi-polar items compiled, was based on semantic differentials developed by Osgood et al. (1957), Appelbaum and Anatol (1973), Boyd et al. (1985), Weiers (1988) and Cooper and Emory (1995).

\section{Measuring perceptions:}

Respondents were shown a separate slide of the corporate logo of each company. While viewing each logo, the respondents had to complete the item semantic differential for that particular industry.

The following wording appeared at the top of the Semantic Differential:

Study (company's name) logo briefly. Please describe how you perceive (company), on the basis of the logo you see, by placing an " $\mathrm{X}$ " on the appropriate number at each of the scales below.

An important factor in compiling semantic differentials is the space (visualised in a numerical scale) between the adjectives or set of bi-polar items. The number of segments between these adjectives suggests a step-by-step movement in 
meaning (perception) between the adjectives (Boyd et al., 1985). In the SD used in these studies the following serves as an example of how the set of bi-polar items was presented:

\begin{tabular}{|l|l|l|l|l|l|l|}
\hline good & 5 & 4 & 3 & 2 & 1 & bad \\
\hline dirty & 1 & 2 & 3 & 4 & 5 & clean \\
\hline friendly & 5 & 4 & 3 & 2 & 1 & unfriendly \\
\hline
\end{tabular}

The technique by Fiedler (1985) of alternating the sets of items from positive to negative was used to reduce the chance of respondents simply marking the scale on either the left or the right hand side.

\section{The respondents:}

Students in the marketing and communication classes at the University of Pretoria were chosen as respondents for studying the corporate image of:

- banking institutions (second-year marketing class);

- petrol (second- and third -year marketing classes);

- fast food companies (second- and third-year marketing and second- and third-year communication classes);

- fashion retailers (home economic students - from first to fourth and final year).

No sampling was done.

A wide variety of students attend the marketing and communication courses. They ranged from those who major in marketing or communication to those who major in hotel and tourism management, personnel management, business management and financial management.

It was assumed that the respondents would understand the importance of giving honest answers for the sake of useful marketing research. No evidence was found in any of the studies that the respondents deliberately tried to falsify their answers.

The corporate logo as cognitive stimulus:

The study conducted by Van Heerden (1993) confirmed that the corporate logo, as one element of the corporate identity mix, may create tangible images in the mind of the respondent because it serves as a "mental switch" or stimulus. The follow-up studies by Van den Berg (1995), Beisiegel (1996) and Gouverneur (1997) were based on this view. 
It was therefore inferred that the following view holds for all industries: The logo reminds the viewer of his/her perceptions, experiences, attitudes, expectations, desires, thoughts, and aversions relating to the corporation "behind" the logo. This view ties in with the argument by Macinnes and Price (1987) that information (on corporations) is not stored as images; rather, knowledge structures are activated, which recall mental images in response to certain stimuli (e.g. seeing the logo).

Exposing the respondents to the different corporate logos and then requiring them to complete the same semantic differential, was therefore regarded as a valid research association.

The data of each of the researchers showed good reliability, and various factors were identified for each industry. This confirms the view that corporate behaviour as well as corporate visual identity contribute to the corporate image. It also confirms that a corporate logo can create tangible images in the minds of the respondents, because it serves as a "mental switch" or stimulus.

Factor analysis:

This is a method used for assessing the interrelationships between a large set of variables for the purpose of reducing it to a smaller set of hypothetical factors (Smith, 1988).

The main purpose of factor analysis of the completed semantic differentials was therefore to "determine linear combinations of variables that will aid the researcher in investigating interrelationships between these variables" (Zikmund, 1991).

Initially no distinction was made between visual and behavioural sets of bi-polar items. Beisiegel (1996) did however distinguish between them and before she analysed the data, the variables/items in the SD were classified as being either a visual (V) attribute or a behavioural (G) attribute. This led to better understanding of the interpretation of factors. Gouverneur (1997) also included dependent and independent variables in her factor analysis.

\section{FINDINGS}

\section{Reliability:}

Beisiegel (1996) used the internal consistency method to measure the reliability of the results obtained in her investigation. Cronbach's alpha coefficient method, randomly selects multiple pairs of subsets from an instrument, correlates each pair's scores, and then uses the composition correlation between all the paired 
subsets as an index of the total instrument's internal consistency (Smith, 1988). The other researchers did not use this method.

Factor analysis:

A factor analysis subsequently enabled the students to summarise thousands of responses into a smaller number of factors. By summarising such a large number of responses, it was hoped that certain underlying constructs or dimensions of the corporate image would be found.

Two indices are especially important for interpreting factor analytical findings. First, factor loadings are coefficients that register the magnitude and direction of a relationship between variables and its underlying hypothetical factor. The closer a factor loading is to unity (1), the stronger is the variable-factor relationship, or the more "highly loaded" is the variable said to be.

By employing the Factor Loading Varimax Normalised Method, a related factor pattern was compiled. Only items scoring more than 0,5 during this procedure were included in the relevant factors.

The relevant factors identified in the various industries are shown in tables 1 to 4:

Table 1 Factors determining corporate image of banking institutions in South Africa (Van Heerden, 1993)

\begin{tabular}{|l|l|l|c|}
\hline & Factor & Attribute & $\begin{array}{l}\% \text { of variance } \\
\text { explained }\end{array}$ \\
\hline Factor 1 & Dynamism & (behaviour and visual) & 50,78 \\
\hline Factor 2 & Stability/credibility & (behaviour) & 4,91 \\
\hline Factor 3 & $\begin{array}{l}\text { Client/customer } \\
\text { service }\end{array}$ & (behaviour) & 3,73 \\
\hline Factor 4 & Visual identity & (visual) & 3,61 \\
\hline \multicolumn{2}{|l|}{} & $63,04 \%$ \\
\hline
\end{tabular}


Table 2 Factors determining the corporate image of South African fashion retailers (Van den Berg, 1994)

\begin{tabular}{|l|l|l|c|}
\hline & Factor & Attribute & $\begin{array}{l}\% \text { of variance } \\
\text { explained }\end{array}$ \\
\hline Factor 1 & Quality merchandise & (visual) & n/a \\
\hline Factor 2 & Customer service & (behaviour) & $\mathrm{n} / \mathrm{a}$ \\
\hline Factor 3 & Location & (visual) & $\mathrm{n} / \mathrm{a}$ \\
\hline & & $55,2 \%$ \\
\hline
\end{tabular}

Table 3 Factors determining the corporate image of petrol companies in South Africa (Beisiegel, 1996)

\begin{tabular}{|l|l|l|c|}
\hline & Factor & Attribute & $\begin{array}{c}\% \text { of variance } \\
\text { explained }\end{array}$ \\
\hline Factor 1 & $\begin{array}{l}\text { Visual/Physical } \\
\text { appearance }\end{array}$ & (visual) & 22,7 \\
\hline Factor 2 & $\begin{array}{l}\text { Customer service/ } \\
\text { Personnel }\end{array}$ & (behaviour) & 20,5 \\
\hline Factor 3 & Dynamism & $\begin{array}{l}\text { (behaviour and } \\
\text { visual) }\end{array}$ & 14,0 \\
\hline
\end{tabular}

Table 4 Factors determining the corporate image of fast food outlets in South Africa (Gouverneur, 1997)

\begin{tabular}{|l|l|l|c|}
\hline & Factor & Attribute & $\begin{array}{l}\% \text { of variance } \\
\text { explained }\end{array}$ \\
\hline Factor 1 & Behavioural identity & (behaviour) & 35,24 \\
\hline Factor 2 & Core product image & (visual) & 6,89 \\
\hline Factor 3 & Core value image & $\begin{array}{l}\text { (behaviour and } \\
\text { visual) }\end{array}$ & 5,67 \\
\hline Factor 4 & Visual recognition & (visual) & 5,56 \\
\hline
\end{tabular}

These results lead to the conclusion that both visual and behavioural factors influence the corporate image and that the Model set out in section 2.7 above, may be accepted as a workable explanation of the corporate image process. 
Correlation:

- Beisiegel (1996) also drew a correlation between the visual and behavioural attributes into a correlation matrix - which is used to display coefficients for more than two variables. In her study, the correlation between the visual and behavioural attributes was $88 \%$ at a $95 \%$ significance level. A recommendations for further research needs to be stated: Determine a dependent variable, such as, loyalty, repurchase, goodwill, support, etc. This will aid further statistical analysis. It would also be an interesting exercise to determine which visual and/or behavioural aspect has the strongest influence on the corporate image.

\section{LIMITATIONS}

The following limitations should be stated:

- no sampling was done;

- the respondents used in this investigation may not be representative of the South African population as a whole to make generalisation of the results possible;

- the list of bi-polar items used in the semantic differential might have been more complete, seeing that the possibility exists that certain important items were excluded;

- not all companies in each of the industries were included in the various studies;

- the factors identified as contributing to a corporate image may only be relevant to the particular companies included in these studies.

These limitations do not detract from the importance of the results, which proved that corporate image is created by both visual and behavioural corporate identity cues.

\section{CONCLUSION}

A semantic differential was designed in these research projects to measure the corporate image of selected South African companies. A subsequent factor analysis of data identified the various factors contributing to the corporate image of these companies.

The research results confirm the view that corporate behaviour and corporate visual identity both serve to create the corporate image. It is also confirmed that the corporate logo can create tangible images in the minds of respondents because it serves as a "mental switch" or stimulus. 
The view that corporate behavioural characteristics are important in the creation of a corporate image, has some significant implications for management. It emphasises that management should spend more time on aspects such as customer service and implement appropriate management styles, than recruiting consultants to trifle with corporate colours, logos and slogans.

In other words, management should apply more time, effort and attention to analysing corporate behaviour than designing corporate visual artefacts.

An outline of literature and the results of four different studies reported in this article have lead to the design of a Corporate Image Process Model which is open to debate, further research and refinement.

\section{REFERENCES}

1 ABRAMIC, K. (1993) "Touting Your Talents", American Printer, 212(2), November: $52-5$.

2 ABRATT, R. (1989) "A new approach to the Corporate Image Management Process", Journal of Marketing Management, 5(1): 63-76.

3 APPELBAUM, R.L., \& ANATOL, K.W.E. (1973), "Dimensions of Source Credibility: A Test for Reproducibility", Speech Monographs, 40: 231-7.

4 BAND, W.A. (1987) "Build Your Company Image to Increase Sales", Sales \& Marketing in Canada, 28(11) December: 10-11.

5 BEISIEGEL, K. (1996) An Exploratory Investigation into the Corporate Image of South African Petrol Companies, Unpublished Industry Research Report at the University of Pretoria.

6 BELLHOUSE, I. (1989) "Corporate Identity: Are the Sceptics Justified?" Industrial Marketing Digest (UK), 14(4), Fourth Quarter: 109-14.

7 BERNSTEN, D. (1986) Company Image and Reality - A Critique of Corporate Communication, Holt, Rinehart and Winston: East Sussex.

8 BOYD, H.W., WESTFALL, R. and STASCH, S.F. (1985) Marketing Research, 6 ed., Richard D Irwin: Homewood, Illinois.

9 COOPER, D.R. and EMORY, C.W. (1995), Business Research Methods. Fifth Edition. Irwin, US.

10 CROFT, M. (1989), "Beyond the Corporate Logo", Accountancy (UK), 104(1152), August: 65-6.

11 CULLEN, D. (1991) "Good Looks Count", Fleet Owner, 86(6) June: 6871.

12 GOUVERNEUR, A. (1997) "An Exploratory Investigation into the Corporate Image of South African Fast-Food Companies", Unpublished Industry Research Report at the University of Pretoria. 
13 FIEDLER, F.E. (1985) "The Leadership Game: Matching the Man to Situation", in Gibson, J.W. and Hodgetts, R.M. (eds.) Readings and Exercises in Organizational Communication, Academic Press, Orlando, Florida: 122-30.

14 GREGORY, J. (1991) Marketing Corporate Image: The Company is your Number One Product, NTC Publishing Group, USA.

15 HARRIS, B. (1995) "Corporate Identity Makes the Difference", Asian Business, 31(10) October: 87.

16 IND, N. (1990) The Corporate Image: Strategies for Effective Identity Programmes, Kogan Page, London.

17 KATZ, M. (1988) "Corporate Identity Programs Don't Have to be Real Expensive", Bank Marketing, 20(4), April: 38-40.

18 KOTLER, P. (1988) Marketing Management, Prentice-Hall International Editions, New Jersey.

19 KOTLER, P. \& ARMSTRONG, G. (1993) Marketing - An Introduction, 3 ed. Prentice-Hall: Englewood Cliffs, New Jersey.

20 LENER, J. (1989) "Seize tomorrow's Markets: Eight Steps to Master your Entrepreneurial Advantage", Success, 36(8), October: 25-42.

21 MACINNES, D.J. \& PRICE, L.L. (1987) "The Role of Imagery in Information Processing: Review \& Extensions", Joumal of Consumer Research, 13, March: 473-91.

22 MILLER, C.D. (1990) "Building a Corporate Identity", Black Enterprise, 20(11), June: 295-8.

23 OLINS, W. (1989) Corporate Identity: Making Business Strategy Visible Through Design, Thames and Hudson.

24 OSGOOD, C.E., SUCI, G.J. and TANNENBAUM, P.H. (1957) The Measurement of Meaning, University of Illinois Press, Urbana.

25 PITT, L. \& NEL, D. (1989) "Student Surrogation in Behavioral Business Research: A Review and Decision Process Model", Management Research News, 12(6): 13-19.

26 SELAME, E. \& SELAME, J. (1988) The Company Image: Building your Identity and Influence in the Market Place, John Wiley \& Sons, New York.

27 SKINNER, C. \& VON ESSEN, L. (1991) The Handbook of Public Relations. 3 ed., Southem Book Publishers, Halfway House (SA).

28 SMITH, M.J. (1988) Contemporary Communication Research Method, Wadsworth, Belmont.

29 STANTON, W.J., ETZEL, M.J. and WALKER, B.J. (1991) Fundamentals of Marketing, 9 ed., McGraw-Hill, New York.

30 STERNBERG, R. (1991) "Making Up a Face to Fit", Asian Business (Hong Kong), 27(4), April: 55-6.

31 STEWART, K. (1991) "Corporate Identity: A Strategic Marketing Issue", Journal of Bank Marketing (UK), 9(1): 32-9. 
32 SUNTER, C. (1993) Future Scenarios for South Africa, Prestige Lecture series no 1. Faculty of Business Economics, University of Pretoria.

33 THOMAS, H. (1988) "Design in Marketing: Can we See your ID please?", Marketing (UK), February 25: 48-51.

34 VAN DEN BERG, M. (1994) An Exploratory Investigation into the Corporate Image of South African Fashion Retailers, Unpublished Industry Research Report at the University of Pretoria.

35 VAN HEERDEN, C.H. (1993) Corporate Identity as an Element of Marketing Strategy, Mcom Dissertation. University of Pretoria.

36 VAN HEERDEN, C.H. (1994) "There is More Corporate Image than Meets the Eye", Image \& Text - A Journal for Design, 4: 3-8.

37 WEIERS, R.M. (1988) Marketing Research, 2 ed., Prentice-Hall, New Jersey.

38 ZIKMUND, W.G. (1991) Exploring Marketing Research, Dryden Press International Edition, Orlando, Florida. 